\title{
Studies on Liquefaction Time and Proteins Involved in the Improvement of Seminal Characteristics in Dromedary Camels (Camelus dromedarius)
}

\author{
Gorakh Mal, ${ }^{1,2}$ Sumant Vyas, ${ }^{1}$ Alagiri Srinivasan, ${ }^{3}$ Nitin Vasant Rao Patil, ${ }^{1}$ \\ and Krishan Murari Lal Pathak ${ }^{4}$ \\ ${ }^{1}$ National Research Centre on Camel, Bikaner, Rajasthan 334 001, India \\ ${ }^{2}$ Indian Veterinary Research Institute, Regional Station, Palampur 176 061, India \\ ${ }^{3}$ Department of Biophysics, All India Institute of Medical Sciences, New Delhi 110 029, India \\ ${ }^{4}$ Indian Council of Agricultural Research (ICAR), Krishi Bhavan, New Delhi 110 001, India \\ Correspondence should be addressed to Gorakh Mal; gorakh14@yahoo.com
}

Received 9 December 2015; Accepted 28 January 2016

Academic Editor: Jacek Kubiak

Copyright (C) 2016 Gorakh Mal et al. This is an open access article distributed under the Creative Commons Attribution License, which permits unrestricted use, distribution, and reproduction in any medium, provided the original work is properly cited.

\begin{abstract}
Semen was collected from six dromedary camels using artificial vagina during rutting season. Liquefaction of the viscous semen occurred in $23.89 \pm 1.49 \mathrm{~h}$. During liquefaction, proteins with molecular masses of $24.55 \mathrm{kDa}$ and $22.07 \mathrm{kDa}$ appeared in conjunction with the disappearance of intact $26.00 \mathrm{kDa}$ protein after $18-24 \mathrm{~h}$. These proteins were identified as $\beta$-nerve growth factors $(\beta$ NGFs) in liquefied camel semen. Guanidine-HCL improves the rheological characteristics of dromedary camel semen along with significant $(P<0.01)$ increase in sperm motility. No significant differences were found in viability of spermatozoa indicating no visible detrimental effects on spermatozoa. The cause of semen viscosity, as well as proteins that are present in liquefied dromedary camel seminal plasma, is described for the first time.
\end{abstract}

\section{Introduction}

Earlier studies carried out on semen evaluation revealed that dromedary camel's spermatozoa are densely clustered and the heads of spermatozoa are embedded and tightly secured and some process of liquefaction of semen coagulum releases spermatozoa in batches, which develop progressive motility [1]. Dromedary camel semen is highly viscous in nature, exhibits low progressive motility, and liquefies slowly. The viscous seminal plasma is currently the major hurdle for the development of assisted reproductive technologies (ARTs) in dromedary camels. Due to viscosity of the ejaculated semen, AI technology in dromedary camels is lacking, which needs to be liquefied before its evaluation [2]. It is necessary to discover the cause of the viscosity and gain an understanding of the role of seminal plasma components in sperm function and fertility. Absence of sperm motility has also been reported [3-5]. These workers have emphasized investigating the factors responsible for the lack of sperm motility in camel semen. No systematic study has been carried out so far regarding the coagulum formation in camel semen and factors responsible for its liquefaction. Higher concentrations of calcium $(\mathrm{Ca})$, zinc $(\mathrm{Zn})$, and iron $(\mathrm{Fe})$ might play an important role in the process of coagulation and liquefaction of dromedary camel semen [6]. Differential protein profiles expression was observed in dromedary seminal plasma [7]. The process of coagulation and liquefaction has been studied in the rat [8,9], guinea pig [10], and human [11-16]. Following ejaculation in the human, a soft clot is formed that then dissolves over 5-20 min [17]. Following dissolution of the clot, a postliquefaction period ensues during which further proteolytic degradation occurs to produce low molecular mass proteins [18]. The major structural components of human semen coagulum have been described as disulfidelinked complexes known as SgI and SgII. Further, it was found that SgI complexes have the property to block the sperm motility. In human, SgI and SgII are secreted form seminal vesicles, which are found to be absent in camel. In the case 
of dromedary semen, the spermatozoa are entrapped in a fibrinous network and thus it needs to be liquefied before the spermatozoa are free and the sample becomes homogenous. Collagenase, fibrinolysin, hyaluronidase, and trypsin have all been used to reduce the viscosity of camelid semen; however, all the enzymes have been seen to cause acrosomal damage in spermatozoa [3]. Semen liquefies with collagenase [2] but there was reduced motility of spermatozoa after its dilution with different extenders and storage at room or refrigeration temperature indicating that the enzymes do have some detrimental effects on the spermatozoa. Collagenase type I improved the rheological characteristics of dromedary camel semen [19].

The objectives of this study were to know the liquefaction time, identification of the proteins involved in this process, and improvement of rheological characteristics of camel semen.

\section{Materials and Methods}

2.1. Semen Collection and Preparation of Seminal Plasma. The study was conducted on 6 Jaisalmeri breed camels (Camelus dromedarius) belonging to the National Research Centre on Camel, Bikaner, India. The animals were apparently healthy and were maintained under uniform standard conditions of feeding and management. The research program was approved by the institute research and ethical committee. Semen samples were collected twice a week using artificial vagina during rutting season (December to March) as described previously [4].

2.2. Time Course Study of the Liquefaction. Two time course studies were carried out to know the liquefaction time at refrigerated temperature. Samples were divided into 2 parts. One portion of ejaculate was evaluated for the changes in semen rheological characteristics by pipetting semen at different time intervals. No thread formation in semen was considered to be liquefied semen. The other portion was centrifuged at $6000 \mathrm{rpm}$ for $30 \mathrm{~min}$ [20] and aliquots of seminal plasma were taken out at different time intervals to compare the protein profiles of fresh (i.e., clotted) versus aliquoted samples (i.e., liquefied samples). Cocktail of protease inhibitor $(100 \mu \mathrm{L}$ protease inhibitor cocktail used/mL of seminal plasma, Sigma-Aldrich, USA, catalogue number P8340) was added in aliquoted samples to inhibit the proteolytic activity and stored at $-196^{\circ} \mathrm{C}$ until it was used. Protein concentrations for each time point were determined and samples were processed for SDS-PAGE.

2.3. One-Dimensional Sodium Dodecyl Sulfate-Polyacrylamide Gel Electrophoresis (1D SDS-PAGE). Protein concentration was determined using the Pierce BCA protein quantification assay (Pierce, Rockford, IL, USA) according to the manufacturer's instructions. Seminal plasma samples were reduced in Laemmli buffer and SDS-polyacrylamide gel electrophoresis of seminal plasma proteins was carried out [21]. The proteins on gels were visualized by Coomassie Brilliant Blue G-250 (Sigma-Aldrich, St. Louis, Missouri, USA). The molecular weight of the proteins was estimated by using reference protein molecular weight markers: rabbit muscle myosin $(205.0 \mathrm{kDa})$, phosphorylase b $(97.4 \mathrm{kDa})$, bovine serum albumin $(66.0 \mathrm{kDa})$, oval albumin $(43.0 \mathrm{kDa})$, carbonic anhydrase $(29.0 \mathrm{kDa})$, and lysozyme $(14.3 \mathrm{kDa})$.

2.4. Mass Spectrometry, MALDI-TOF/MS Analysis and Identification of $\beta$-NGF. The protein bands $(24.55$ and $22.07 \mathrm{kDa})$ were excised from Coomassie stained SDS-PAGE gel. Mass spectrometry and MALDI-TOF/MS were carried out [22]. The analysis was performed using a Bruker autoflex MALDITOF/MS (Bruker Daltonics) system equipped with $355 \mathrm{~nm}$ ND: YAG laser. The combined MS and MS/MS spectra were deposited to MASCOT version 2.1 (Matrix Science, London, UK) using GPS Explorer software version 3.6 (Applied Biosystems). The number of identified peptides, sequence coverage, and number of MS/MS identified peptides were taken during protein identification.

2.5. Effect of Denaturing Agents on Semen Rheological Characteristics. 36 ejaculates from 6 camels were used to study the effect of various denaturing agents for improving the seminal characteristics. Each ejaculate was divided into 3 parts. One part served as control and the remaining two parts were incubated either with buffer containing $20 \mathrm{mM}$ TRIS + $8 \mathrm{M}$ Urea $+33 \mathrm{mM}$ DTT or with $2.5 \mathrm{M}$ guanidine$\mathrm{HCL}$ at $37^{\circ} \mathrm{C}$ for $5-30 \mathrm{~min}$ for disruption of seminal clot and for the induction of liquefaction. Liquefaction of the semen was assessed by pipetting the semen as described above. Percentages of sperm motility and viability were determined. At least 200 spermatozoa were counted for each group. Sperm viability (\%) was assessed with Eosin-Nigrosin stain. Sperm motility and viability were analyzed using $t$-test [23].

\section{Results}

3.1. Liquefaction of Camel Semen. Complete liquefaction was observed to be $23.89 \pm 1.49 \mathrm{~h}$ varying from 18 to $41 \mathrm{~h}$.

\subsection{Protein Profiles in Liquefied Semen and Identification} of $\beta$-Nerve Growth Factors in Liquefied Semen. 12 protein bands were observed in unliquefied semen and 13 bands were observed in liquefied semen. $\sim 26.00 \mathrm{kDa}$ protein bands were found in fresh seminal plasma and remained stable up to $18-24 \mathrm{~h}$ (as shown in Figures 1-4) with individual animal to animal variations (even up to $41 \mathrm{~h}$ ) and after that these proteins start to degrade as the camel semen starts to liquefy. $26.00 \mathrm{kDa}$ proteins bands have been identified as nerve growth factor. Proteins with molecular masses of $24.55 \mathrm{kDa}$ and $22.07 \mathrm{kDa}$ appeared in conjunction with the disappearance of intact $26.00 \mathrm{kDa}$ protein after $18-24 \mathrm{~h}$. These bands were characterized by mass spectrophotometry; upper and lower bands were identified as degraded nerve growth factors (Table 1).

3.3. Effect of Denaturing Agents in Liquefaction. It was observed that initial motility was found to be nearly zero and spermatozoa were entrapped in the gel so the estimation of motility was not possible. No visible effect on seminal clot was noticed with buffer. However, guanidine-HCL showed 
TABLE 1: Proteins identified in dromedary seminal plasma by MALDI-TOF/MS of the 24.55 and $22.07 \mathrm{kDa}$ bands.

\begin{tabular}{|c|c|c|c|c|c|c|}
\hline Bands position & Protein name & Accession number & $\begin{array}{c}\text { Number of } \\
\text { peptides }\end{array}$ & $\begin{array}{c}\text { Sequence } \\
\text { coverage }\end{array}$ & Peptide sequences & $\begin{array}{c}\text { Database } \\
\text { search }\end{array}$ \\
\hline Upper & $\begin{array}{l}\beta \text {-nerve growth } \\
\text { factor precursor }\end{array}$ & gi/2499187 & 2 & 12.7 & EVMVLGEVNINNSVFKQYFFETK & NCBInr \\
\hline Lower & $\begin{array}{c}\beta \text {-nerve growth } \\
\text { factor }\end{array}$ & gi/73981127 & 2 & 4.6 & GKEVMVLGEVNINNSVFKQYFFETK & NCBInr \\
\hline
\end{tabular}

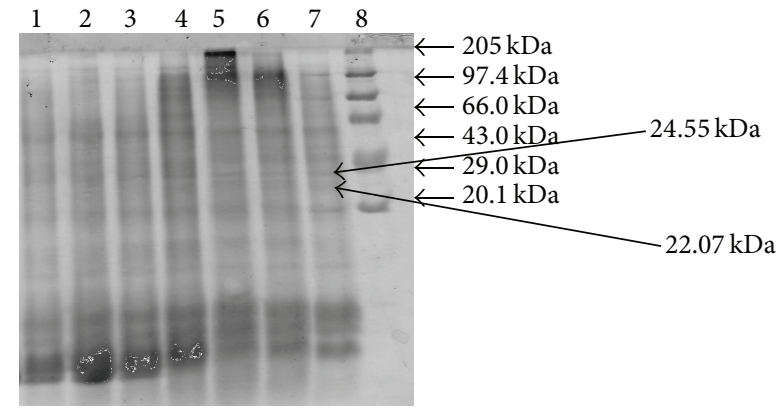

Figure 1: Protein profiles of fresh and liquefied semen. Lane 1, 0 hours; lane 2, $6 \mathrm{~h}$; lane 3, $12 \mathrm{~h}$; lane 4, $18 \mathrm{~h}$; lane 5, 24 h; lane 6, $30 \mathrm{~h}$; lane $7,36 \mathrm{~h}$; and lane 8 , protein markers.

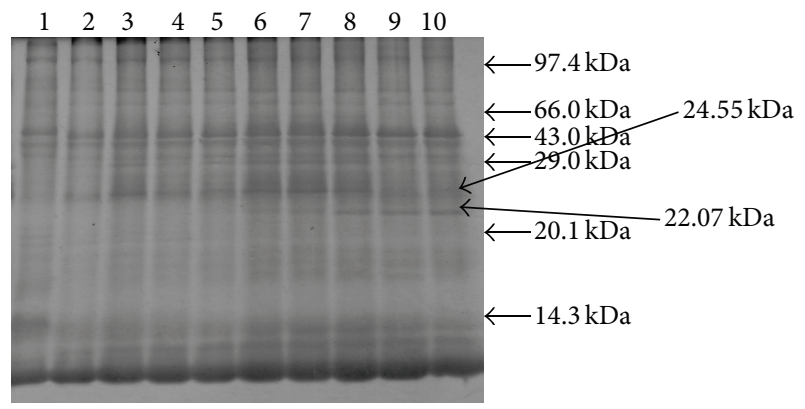

FIGURE 2: Protein profiles of fresh and liquefied semen. Lane 1, 0 hours; lane 2, $6 \mathrm{~h}$; lane 3,12 h; lane 4, $18 \mathrm{~h}$; lane 5, 24 h; lane 6, $30 \mathrm{~h}$; lane 7, $36 \mathrm{~h}$; lane 8, $42 \mathrm{~h}$; lane 9, $48 \mathrm{~h}$; and lane 10, $72 \mathrm{~h}$.

a partial disruption of seminal clot after $30 \mathrm{~min}$ as frequency of thread formation reduced significantly. Thread formation was observed in all freshly ejaculated semen, $77.78 \%$ thread formation was observed in buffer treated semen, and $41.67 \%$ was observed in guanidine-HCL treated semen after $30 \mathrm{~min}-$ utes (Table 2). Initial individual motility in control semen was found to be nil. A significant higher $(P<0.01)$ motility was observed for the semen samples treated with guanidine-HCL compared to buffer treated and control group. No significant differences were found in viability of spermatozoa (Table 2) indicating no visible detrimental effects on spermatozoa.

\section{Discussion}

Hyperviscous nature of camel semen may have advantages in preventing sperm losses. The time of liquefaction of semen in dromedary camels was 4.5 to $9.6 \mathrm{~min} \mathrm{[24]} \mathrm{and} 8$ to $48 \mathrm{~h}$ in alpaca camels [25], while a liquefaction time of $23.89 \pm 1.49 \mathrm{~h}$

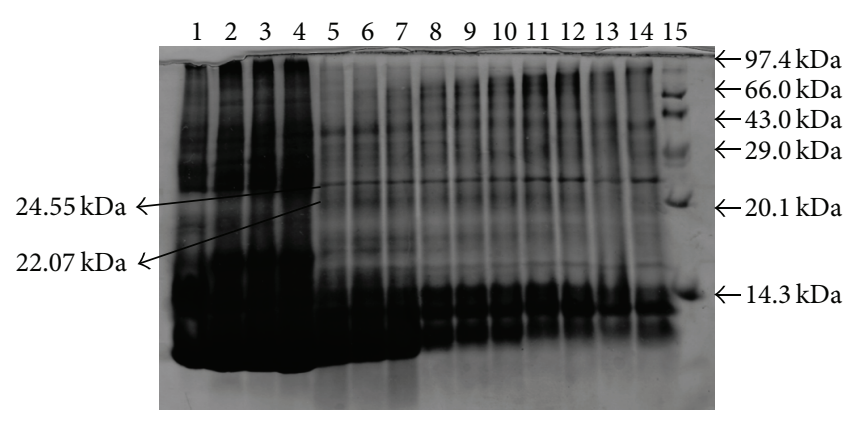

FIgURE 3: Protein profiles of fresh and liquefied semen. Lane 1, 0 hours; lane 2, $6 \mathrm{~h}$; lane 3, $12 \mathrm{~h}$; lane 4, $18 \mathrm{~h}$; lane 5, $24 \mathrm{~h}$; lane 6, $30 \mathrm{~h}$; lane 7, $36 \mathrm{~h}$; lane 8, $42 \mathrm{~h}$; lane 9, $48 \mathrm{~h}$; lane 10, $54 \mathrm{~h}$; lane 11, $60 \mathrm{~h}$; lane 12, $66 \mathrm{~h}$; lane 13, $72 \mathrm{~h}$; lane 14, $84 \mathrm{~h}$; and lane 15, protein markers.

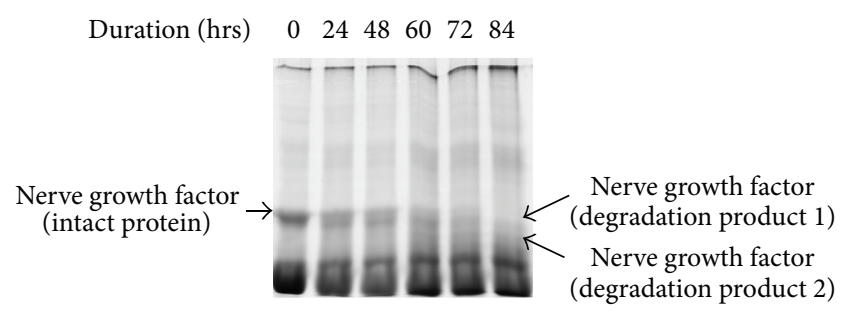

FIGURE 4: SDS-PAGE for identification of $\beta$-nerve growth factor in camel semen. Lane 1, 0 hours; lane 2, 24 h; lane 3, 48 h; lane 4, $60 \mathrm{~h}$; lane 5, 72 h; and lane 6, $84 \mathrm{~h}$.

was found in dromedary camel semen in the present study.

In human semen hyperviscous seminal plasma may cause asthenozoospermia [26]. The existence of a highly organized network of disulfide bonds, oligosaccharide and peptide chains in seminal plasma, responsible for the rheological characteristics of ejaculates with high viscosity was suggested [27]. These molecules, which would be responsible for the hyperviscous rheological behavior, could be a key factor in sperm physiology and, therefore, in sperm motility.

The electrophoretic patterns of camel seminal plasma revealed the presence of 10 to 14 protein fractions [24].

$\beta$-nerve growth factor in fresh ejaculated semen of dromedary camel was identified [22]. During time course study, it was observed that this protein undergoes fragmentation to yield 2 bands of $24.55 \mathrm{kDa}$ and $22.07 \mathrm{kDa}$ approximately in size in liquefied semen. These proteins were identified as $\beta$-nerve growth factors. $\beta$-NGFs appeared to remain in the liquefied semen up to $84 \mathrm{~h}$ (i.e., the duration up to which experiment was conducted). 


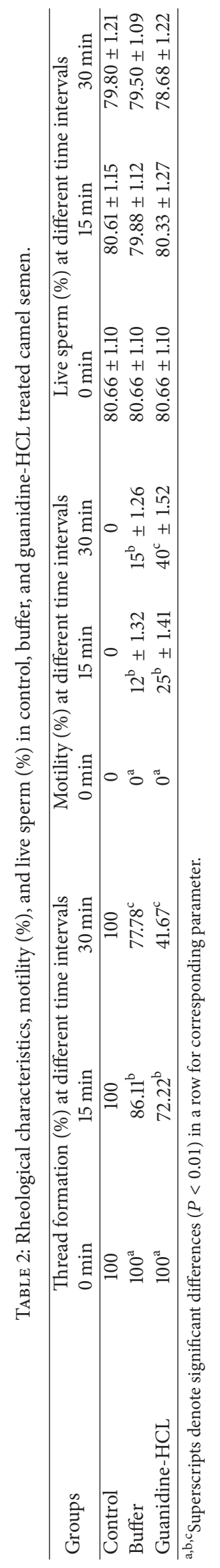


Enzymatic treatments used in bactrian and alpaca semen have decreased the viscosity but deleterious effects on spermatozoa were observed [28-33]. In our study, reduction in thread formation along with significant increase in motility was observed in guanidine-HCL treated samples. An increase in sperm motility might be due to guanidine-HCL by modifying semen rheological characteristics. Effect of different extenders (Citrate yolk, Tris fructose yolk, Androhep, Laciphos, Green Buffer) on the semen viscosity and sperm viability of the dromedary camel was studied [34] and a beneficial effect of adding extenders on liquefaction of camel semen and sperm motility was found. No posttreatment deleterious effect was observed on sperm viability. $0.1 \%$ collagenase was reported to be improving the rheological characteristics of dromedary camel semen [19].

\section{Conclusions}

Time course studies on liquefaction indicated protein transformation and a definite role of $\beta$-NGF in the process of liquefaction. $\beta$-NGF proteins appeared from $24 \mathrm{~h}$ onwards and remain up to $84 \mathrm{~h}$ in liquefied semen. Recently, experiments carried out by different workers revealed that nerve growth factors are also involved in ovulation induction in alpaca camels. The results obtained in this study show that treatment with $2.5 \mathrm{M}$ guanidine-HCL provides a way to enhance dromedary semen rheological characteristics, permitting the separation of spermatozoa from seminal plasma and promoting sperm progressive motility. It will be of pertinent interest to study the sperm interactions of the liberated cleavage products of the unfragmented protein. The role of seminal plasma proteins in sperm function in dromedary camels requires further research.

\section{Conflict of Interests}

The authors declare that there is no conflict of interests regarding the publication of this paper.

\section{References}

[1] A. Deen, S. Vyas, and M. S. Sahani, "Semen collection, cryopreservation and artificial insemination in the dromedary camel," Animal Reproduction Science, vol. 77, no. 3-4, pp. 223233, 2003.

[2] N. A. Wani, M. Billah, and J. A. Skidmore, "Studies on liquefaction and storage of ejaculated dromedary camel (Camelus dromedarius) semen," Animal Reproduction Science, vol. 109, no. 1-4, pp. 309-310, 2008.

[3] A. Tibary and A. Anouassi, Theriogenology in Camelidae, Ministry of Agriculture and Information, Dubai, UAE, 1st edition, 1997.

[4] S. Vyas, P. Goswami, A. K. Rai, and N. D. Khanna, "Use of tris and lactose extenders in preservation of camel semen at refrigerated temperature," Indian Veterinary Journal, vol. 75, no. 9, pp. 810-812, 1998.

[5] V. K. Agarwal, L. Ram, A. K. Rai, N. D. Khanna, and S. P. Agarwal, "Physical and biochemical attributes of camel semen," Journal of Camel Science, vol. 1, pp. 25-30, 2004.
[6] G. Ma, S. Vyas, N. Saini, D. S. Sena, N. Kishore, and N. V. Patil, "Mineral status of blood and semen of dromedary camels," Indian Veterinary Journal, vol. 88, no. 8, pp. 72-73, 2011.

[7] G. Mal, S. Vyas, and N. V. Patil, "Comparative study of seminal plasma proteins in dromedary camels," Indian Journal of Animal Sciences, vol. 84, no. 1, pp. 13-14, 2014.

[8] E. Schon, J. Lukac, and S. Milkovic, "A new proteinaceous factor participating in the rat ejaculate coagulation-identification, isolation and function," Biology of Reproduction, vol. 26, no. 5, pp. 875-884, 1982.

[9] H. G. Williams-Ashman, "Transglutaminases and the clotting of mammalian seminal fluids," Molecular and Cellular Biochemistry, vol. 58, no. 1-2, pp. 51-61, 1984.

[10] A. C. Notides and H. G. Williams-Ashman, "The basic protein responsible for the clotting of guinea pig semen," Proceedings of the National Academy of Sciences of the United States of America, vol. 58, no. 5, pp. 1991-1995, 1967.

[11] P. F. Tauber, L. J. D. Zaneveld, D. Propping, and G. F. B. Schumacher, "Components of human split ejaculates. II. Enzymes and proteinase inhibitors," Journal of Reproduction and Fertility, vol. 46, no. 1, pp. 165-171, 1976.

[12] E. Koren and J. Lukac, "Mechanism of liquefaction of the human ejaculate. I. Changes of the ejaculate proteins," Journal of Reproduction and Fertility, vol. 56, no. 2, pp. 493-499, 1979.

[13] J. Lukac and E. Koren, "Mechanism of liquefaction of the human ejaculate. II. Role of collagenase-like peptidase and seminal proteinase." Journal of Reproduction and Fertility, vol. 56, no. 2, pp. 501-506, 1979.

[14] H. Lilja and C.-B. Laurell, "Liquefaction of coagulated human semen," Scandinavian Journal of Clinical and Laboratory Investigation, vol. 44, no. 5, pp. 447-452, 1984.

[15] H. Lilja and H. Weiber, "Synthetic protease inhibitors and postejaculatory degradation of human semen proteins," Scandinavian Journal of Clinical and Laboratory Investigation, vol. 44, no. 5, pp. 433-438, 1984.

[16] H. Lilja, C.-B. Laurell, and J.-O. Jeppsson, "Characterization of the predominant basic protein in human seminal plasma, one cleavage product of the major seminal vesicle protein," Scandinavian Journal of Clinical and Laboratory Investigation, vol. 44, no. 5, pp. 439-446, 1984.

[17] P. F. Tauber, L. J. D. Zaneveld, D. Propping, and G. F. B. Schumacher, "A new technique to measure the liquefaction rate of human semen: the bag method," Fertility and Sterility, vol. 33, no. 5, pp. 567-570, 1980.

[18] H. Lilja and C.-B. Laurell, "The predominant protein in human seminal coagulate," Scandinavian Journal of Clinical and Laboratory Investigation, vol. 45, no. 7, pp. 635-641, 1985.

[19] C. Shekhar, S. Vyas, G. N. Purohit, and N. V. Patil, "Use of collagenase type-1 to improve the seminal characteristics of dromedary camel semen," European Journal of Veterinary Medicine, vol. 1, no. 1, pp. 17-27, 2012.

[20] G. Mal, N. Saini, D. S. Sena, S. Vyas, and K. M. L. Pathak, "Protein and mineral profiles in the seminal plasma of dromedary camels," Indian Veterinary Journal, vol. 88, no. 3, pp. 82-83, 2011.

[21] U. K. Laemmli, "Cleavage of structural proteins during the assembly of the head of bacteriophage T4," Nature, vol. 227, no. 5259, pp. 680-685, 1970.

[22] S. Kumar, V. K. Sharma, S. Singh et al., "Proteomic identification of camel seminal plasma: purification of $\beta$-nerve growth factor," Animal Reproduction Science, vol. 136, no. 4, pp. 289-295, 2013. 
[23] G. W. Snedecor and W. G. Cochran, Statistical Methods, Iowa State University Press, Ames, Iowa, USA, 8th edition, 1994.

[24] M. El-Naggar and M. Abdel-Raouf, "Studies on reproduction in camels (Camelus dromedarius) VIII. The electrophoretic pattern and the amino acid content of the seminal plasma protein," The Indian Veterinary Journal, vol. 54, no. 4, pp. 239243, 1977.

[25] J. Garnica, R. Achata, and P. W. Bravo, "Physical and biochemical characteristics of alpaca semen," Animal Reproduction Science, vol. 32, no. 1-2, pp. 85-90, 1993.

[26] G. R. Mendeluk, L. G. Flecha, P. Castello, and A. M. Blanco, "Seminal hyperviscosity: possible molecular etiologic factors," Biorheology, vol. 32, pp. 305-306, 1995.

[27] G. R. Mendeluk, L. González, L. G. Flecha, P. Castello, A. M. Blanco, and C. Bregni, "Factors involved in the biochemical etiology of human seminal plasma hyperviscosity," Journal of Andrology, vol. 21, no. 2, pp. 262-267, 2000.

[28] P. W. Bravo, C. Pacheco, G. Quispe, L. Vilcapaza, and C. Ordoñez, "Degelification of alpaca semen and the effect of dilution rates on artificial insemination outcome," Archives of Andrology, vol. 43, no. 3, pp. 239-246, 1999.

[29] P. W. Bravo, M. Ccallo, and J. Garnica, "The effect of enzymes on semen viscosity in Llamas and Alpacas," Small Ruminant Research, vol. 38, no. 1, pp. 91-95, 2000.

[30] P. Poblete, A. von Baer, L. von Baer, and M. del Campo, "Evaluación de la morfología espermática del semen de camélidos sudamericanos tratados con tripsina," Memorias III Congreso Mundial sobre Camélidos Potosí, Bolivia, vol. 2, pp. 765-768, 2003.

[31] $R$ 2.2.1. Program, Version 2.2.1 (2005-12-20r36812), The $\mathrm{R}$ Foundation for Statistical Computing, Vienna, Austria, 2005.

[32] A. Tibary and J. Vaughan, "Reproductive physiology and infertility in male South American camelids: a review and clinical observations," Small Ruminant Research, vol. 61, no. 2-3, pp. 283-298, 2006.

[33] C. W. M. Maxwel, G. Evans, and K. M. Morton, "The development of collection, processing and storage technologies for alpaca semen," in Extender Abstracts WBC/ICAR Satellite Meeting on Camelid Reproduction, pp. 19-25, Budapest, Hungary, July 2008.

[34] I. Ghoneim, M. Al-Eknah, M. M. Waheed, A. K. Alhaider, and A. M. Homeida, "Effect of some extenders and enzymes on semen viscosity and sperm viability in dromedary camels," Journal of Camel Practice and Research, vol. 17, no. 1, pp. 85-89, 2010. 

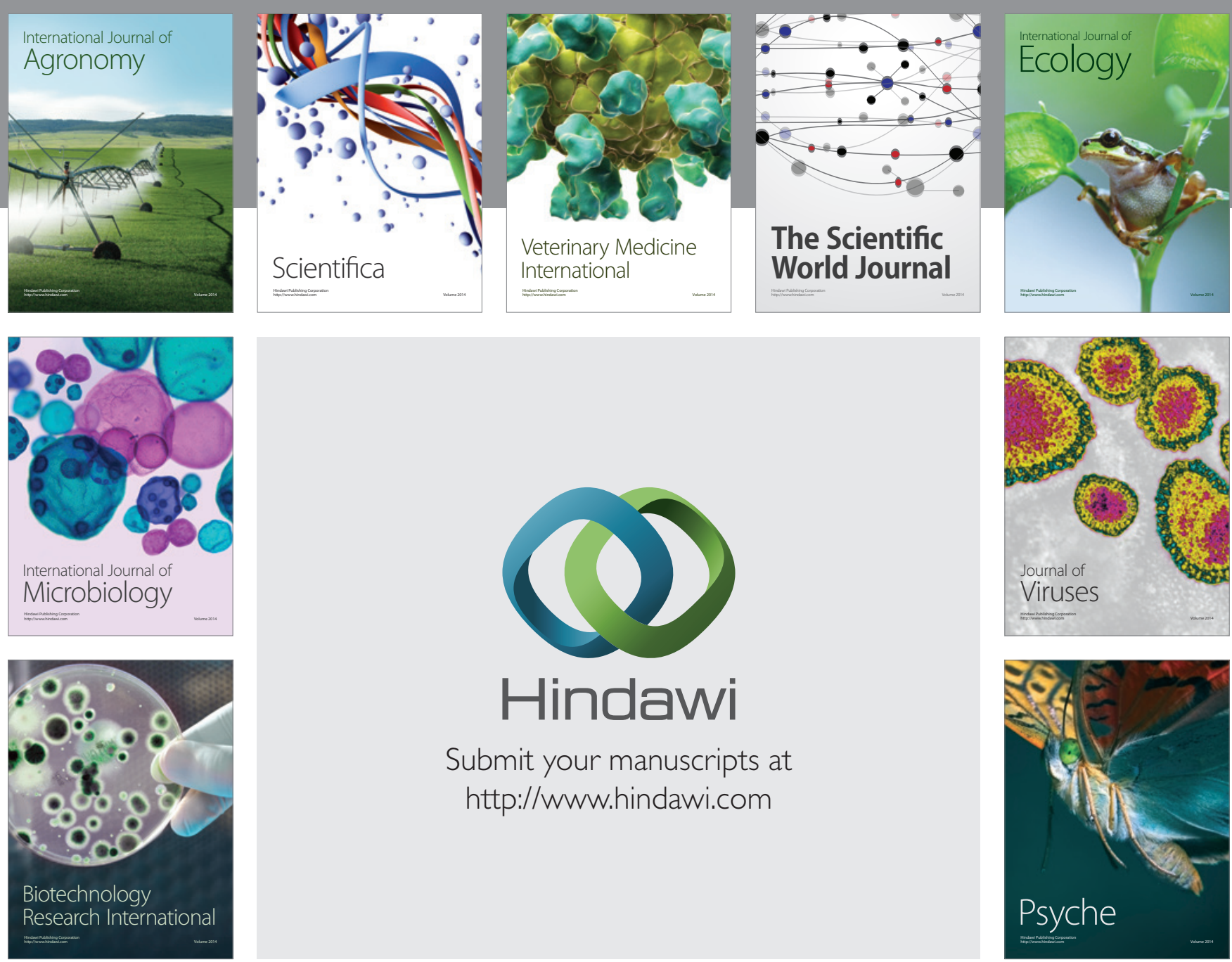

Submit your manuscripts at

http://www.hindawi.com
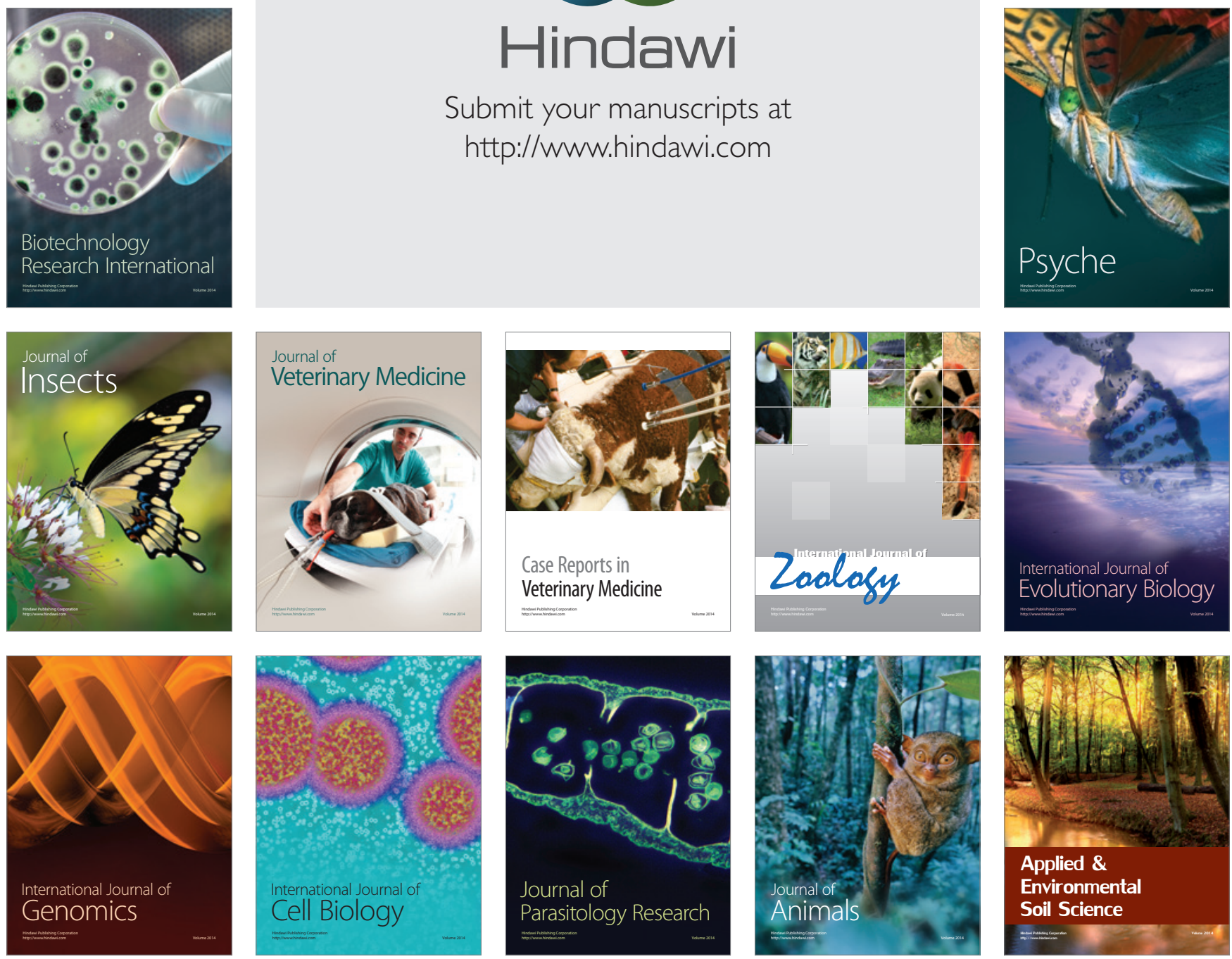